\title{
Intestinal obstruction caused by primary adenosquamous cell carcinoma of the small intestine: A case report and review of the literature
}

\author{
NAOTAKE FUNAMIZU, YUKIO NAKABAYASHI, KATSUSHI DAIRAKU, \\ KENTA TOMORI, YUKI HIRAMOTO and KAZUNAO KURIHARA
}

Department of Digestive Surgery, Kawaguchi Municipal Medical Center, Kawaguchi, Saitama 333-0833, Japan

Received July 18, 2018; Accepted December 3, 2018

DOI: $10.3892 / \mathrm{mco} .2018 .1785$

\begin{abstract}
Primary adenosquamous cell carcinoma (ASCC) arising from the ileum is an exceptionally rare malignant neoplasm exhibiting mixed glandular and squamous differentiation. The clinicopathological characteristics of ASCC have not been clearly determined due to its rarity. We herein report a case of a 74-year-old man with a successfully treated ASCC of the ileum. The patient visited a medical clinic due to abdominal pain. Abdominal computed tomography imaging revealed an intestinal tumor in the ileum. Prior to undergoing capsule endoscopy, the patient complained of severe abdominal pain due to intestinal obstruction from the patency capsule and the tumor. Thus, the patient was referred to our hospital for emergency surgery. Upon relieving the obstruction by partial resection of the ileum, an impacted patency capsule with a tumor with ulceration was identified. On histological examination, the tumor consisted of malignant glandular and squamous cell elements. The postoperative course was uneventful, without complications. The patient subsequently received adjuvant chemotherapy with oxaliplatin and capecitabine for 6 months. The patient has no evidence of recurrence 20 months after surgery. To the best of our knowledge, only 8 cases of ASCC have been reported in the English literature to date. This case serves as an important reminder to consider small intestinal carcinoma, including ASCC, in the differential diagnosis of intestinal obstruction.
\end{abstract}

Correspondence to: Dr Naotake Funamizu, Department of Digestive Surgery, Kawaguchi Municipal Medical Center, 180 Nishi-araijuku, Kawaguchi, Saitama 333-0833, Japan

E-mail: funamizujikei@yahoo.co.jp

Abbreviations: ASCC, adenosquamous cell carcinoma; CT, computed tomography; XELOX, capecitabine + oxaliplatin

Key words: small intestinal tumor, adenosquamous cell carcinoma, ileum

\section{Introduction}

Small intestinal malignant tumors account for $0.4-2.3 \%$ of digestive tract tumors, with carcinoid tumors accounting for $35-42 \%$, adenocarcinomas for 30-40\%, malignant lymphomas for $15-20 \%$ and gastrointestinal stromal tumors for $10-15 \%$ of the cases (1). Adenosquamous cell carcinoma (ASCC) of the small intestine is an extremely uncommon tumor. The World Health Organization has defined ASCC as a tumor that contains at least $10 \%$ adenocarcinomatous and squamous cell carcinomatous components (2). To the best of our knowledge, only 8 cases of ASCC have been reported in the English literature to date. We herein report the 9th case of a primary ASCC of the small intestine.

\section{Case report}

A previously healthy 74-year-old man presented to his local physician with a 2-day history of abdominal pain. Contrast-enhanced computed tomography (CT) imaging of the abdomen revealed a mass in the ileum. For further investigation, capsule endoscopy was scheduled at the clinic. First, a patency capsule was administered as a test run to confirm the patency of the intestine. However, the patient complained of exacerbation of the abdominal pain, as the patency capsule could not pass through the tumor. Therefore, the patient was transferred to the Kawaguchi Municipal Medical Center (Kawaguchi, Japan) for urgent treatment. The results of the physical examination upon admittance were as follows: Blood pressure, 144/82 mmHg; heart rate, 88 beats per min; body temperature, $36.6^{\circ} \mathrm{C}$; body weight, $60.0 \mathrm{~kg}$; and height, $160.0 \mathrm{~cm}$. The physical examination also revealed severe tenderness of the entire abdomen, but no rebound tenderness. The patient had no specific family or medical history. Hematological examination revealed a white blood cell count of $8,900 / \mu \mathrm{l}$ (normal range: 3,500-9,000/ $\mu \mathrm{l}$ ), hemoglobin level of $8.5 \mathrm{~g} / \mathrm{dl}$ (normal range: 14.0-16.0 g/dl), C-reactive protein level of $1.62 \mathrm{mg} / \mathrm{dl}(\leq 0.1 \mathrm{mg} / \mathrm{dl})$, carcinoembryonic antigen level of $3.7 \mathrm{ng} / \mathrm{ml}$ (normal value: $\leq 5.0 \mathrm{ng} / \mathrm{ml}$ ), and cancer antigen 19-9 level of $321.9 \mathrm{IU} / \mathrm{ml}$ (normal value: $\leq 37.0 \mathrm{IU} / \mathrm{ml}$ ). A contrast-enhanced CT of the abdomen revealed the patency capsule lodged in the mass in the ileum, with intestinal dilation cranially, without ascites (Fig. 1). Based on the preoperative 
Table I. Summary of reported cases of adenosquamous cell carcinoma of the small intestine.

\begin{tabular}{|c|c|c|c|c|c|c|c|c|c|c|}
\hline Author & Year & $\begin{array}{l}\text { Age, } \\
\text { years }\end{array}$ & Sex & Symptom & Location & Operation & Stage & $\begin{array}{l}\text { Chemotherapy } \\
\text { regimen }\end{array}$ & $\begin{array}{c}\text { Survival } \\
\text { (months), } \\
\text { outcome }\end{array}$ & (Refs.) \\
\hline Bjerregaard & 1974 & 80 & $\mathrm{~F}$ & $\begin{array}{l}\text { Abdominal } \\
\text { pain }\end{array}$ & Jejunum & Bypass & ND & ND & $\begin{array}{l}0.5, \\
\text { deceased }\end{array}$ & (13) \\
\hline $\begin{array}{l}\text { Griesser } \\
\text { et al }\end{array}$ & 1985 & 74 & M & $\begin{array}{l}\text { Abdominal } \\
\text { pain }\end{array}$ & Ileum & $\begin{array}{l}\text { Partial } \\
\text { resection }\end{array}$ & IIIa & None & ND & (14) \\
\hline $\begin{array}{l}\mathrm{Ng} \\
\text { et al }\end{array}$ & 1993 & 77 & M & $\begin{array}{l}\text { Abdominal } \\
\text { pain }\end{array}$ & Ileum & $\begin{array}{l}\text { Partial } \\
\text { resection }\end{array}$ & IV & None & $\begin{array}{l}3, \\
\text { deceased }\end{array}$ & (15) \\
\hline $\begin{array}{l}\text { Ngo } \\
\text { et al }\end{array}$ & 1999 & 55 & $\mathrm{~F}$ & $\begin{array}{l}\text { Abdominal } \\
\text { pain }\end{array}$ & Ileum & $\begin{array}{l}\text { Partial } \\
\text { resection }\end{array}$ & IV & GEM + 5-FU & $\begin{array}{l}26, \\
\text { alive }\end{array}$ & (16) \\
\hline $\begin{array}{l}\text { Wada } \\
\text { et al }\end{array}$ & 2003 & 70 & $\mathrm{~F}$ & $\begin{array}{l}\text { Abdominal } \\
\text { pain }\end{array}$ & Jejunum & $\begin{array}{l}\text { Partial } \\
\text { resection }\end{array}$ & IIIa & None & $\begin{array}{l}12, \\
\text { deceased }\end{array}$ & (17) \\
\hline $\begin{array}{l}\mathrm{He} \\
\text { et al }\end{array}$ & 2005 & 80 & $\mathrm{~F}$ & $\begin{array}{l}\text { Abdominal } \\
\text { pain }\end{array}$ & Jejunum & $\begin{array}{l}\text { Partial } \\
\text { resection }\end{array}$ & IV & None & $\begin{array}{l}2, \\
\text { deceased }\end{array}$ & (18) \\
\hline $\begin{array}{l}\text { Takayoshi } \\
\text { et al }\end{array}$ & 2016 & 76 & F & $\begin{array}{l}\text { Epigastric } \\
\text { discomfort }\end{array}$ & Duodenum & $\begin{array}{l}\text { Pancreatoduo- } \\
\text { denectomy }\end{array}$ & IIIa & FOLFOX & $\begin{array}{l}27, \\
\text { deceased }\end{array}$ & (19) \\
\hline $\begin{array}{l}\text { Daga and } \\
\text { Kerkar }\end{array}$ & 2016 & 78 & M & $\begin{array}{l}\text { Tarry } \\
\text { stool }\end{array}$ & Duodenum & $\begin{array}{l}\text { Pancreatoduo- } \\
\text { denectomy }\end{array}$ & ND & None & 3 , alive & (20) \\
\hline $\begin{array}{l}\text { Present } \\
\text { case }\end{array}$ & 2018 & 74 & M & $\begin{array}{l}\text { Abdominal } \\
\text { pain }\end{array}$ & Ileum & $\begin{array}{l}\text { Partial } \\
\text { resection }\end{array}$ & IIIa & XELOX & 20 , alive & \\
\hline
\end{tabular}

ND, not described; GEM, gemcitabine; XELOX, capecitabine + oxaliplatin; FOLFOX, fluorouracil + leucovorin + oxaliplatin.

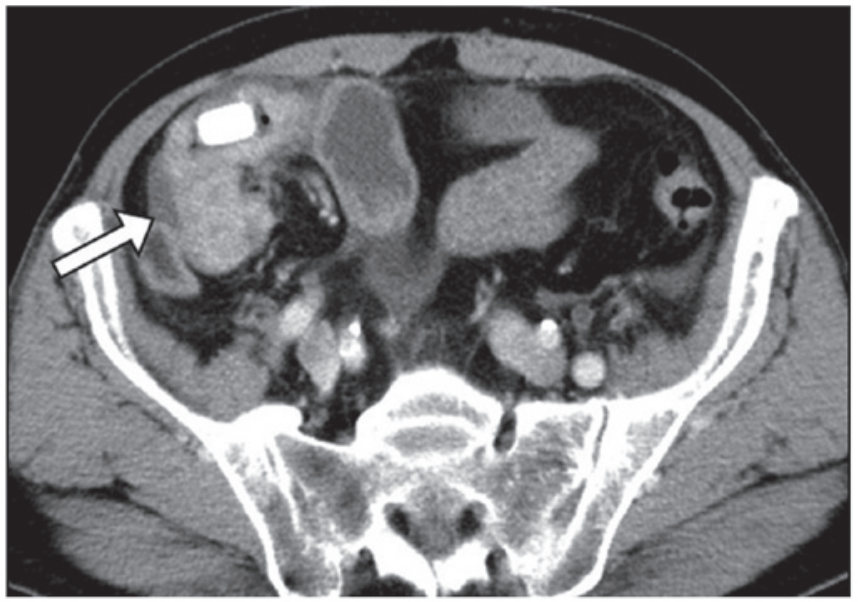

Figure 1. Contrast-enhanced abdominal computed tomography imaging revealed a mass, $45 \mathrm{~mm}$ in greatest diameter, with an impacted patency capsule, in the right lower abdomen (arrow).

diagnosis of intestinal obstruction due to an intestinal tumor, emergency laparotomy was performed. During the surgery, a hard and immobile mass was detected $40 \mathrm{~cm}$ cranially from the terminal ileum, without peritoneal dissemination or ascites. Moreover, the tumor formed a loop via invasion of the intestine $10 \mathrm{~cm}$ on the caudal side (Fig. 2A). The patient underwent partial resection of the ileum with lymph node dissection. Subsequently, functional end-to-end anastomosis was performed. Following intra-abdominal lavage, the abdominal wall was closed by a 1-layer and continuous technique using non-absorbable sutures.
On macroscopic examination of the resected specimen, an ulcerated tumor was identified, measuring $4.0 \times 2.0 \times 1.5 \mathrm{~cm}$ (Fig. 2B). Microscopically, the tumor comprised malignant squamous and glandular components (Fig. 3A). Moreover, P40 staining confirmed the presence of the squamous component (Fig. 3B). The final histopathological diagnosis was ASCC of the ileum, T4N1M0, stage IIIa. The postoperative course was uneventful, without complications, and the patient was discharged 15 days after surgery. Generally, small intestinal carcinomas are treated according to the Japanese gastric or colorectal cancer guidelines $(3,4)$. Thus, capecitabine + oxaliplatin (XELOX) was administered for 6 months, as XELOX is commonly used as adjuvant chemotherapy of gastric and colon cancer in Japan. The patient has experienced no recurrence 23 months after surgery (as at 10/17/2018).

\section{Discussion}

ASCC is defined as a carcinoma that includes adenocarcinomatous and squamous cell carcinomatous components (5). The mechanism underlying carcinogenesis in ASCC remains elusive. Kardon et al reported that the most convincing theory was metaplastic malignant squamous transformation of adenocarcinoma (6). By contrast, Yang et al reported the following hypotheses: i) Pluripotent epithelial stem cells capable of inducing malignant transformation of adenocarcinoma and squamous cell carcinoma cells; ii) squamous metaplasia of the intestinal mucosa; iii) squamous metaplastic transformation from adenocarcinoma; and iv) collision tumors (7). Primary ASCC has been described in several organs, including 


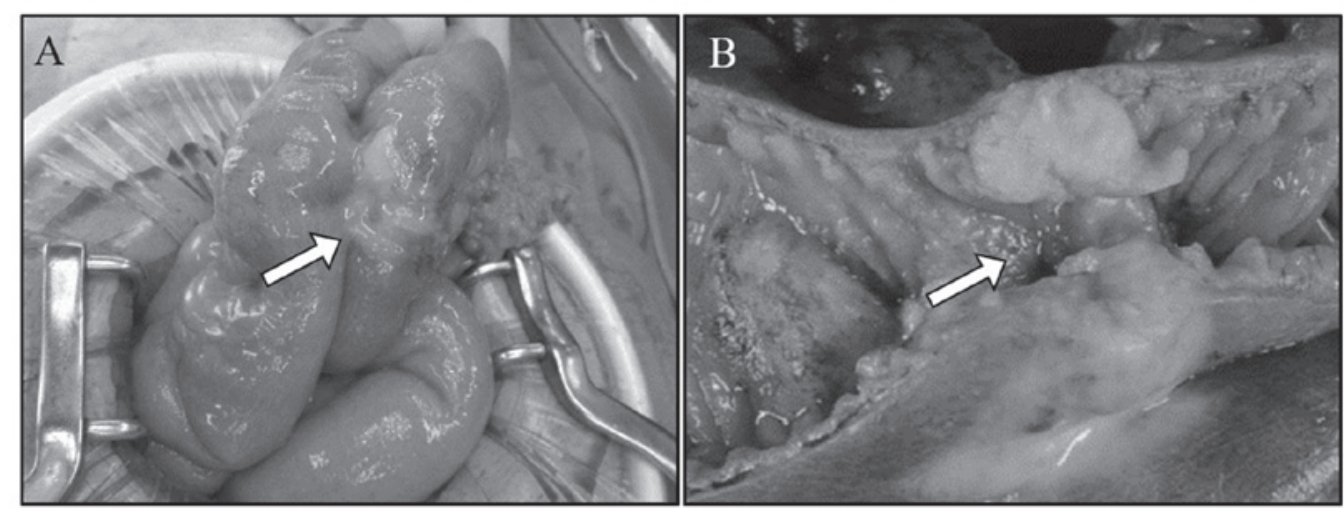

Figure 2. (A) Intraoperatively, the tumor was found to invade the serosa, forming a closed loop by infiltration of the small intestine at a distance of 10 cm caudally (arrow). (B) The resected specimen consisted of a $15-\mathrm{cm}$ segment of the ileum. The tumor mass was $4.0 \mathrm{~cm}$ in greatest diameter and was ulcerated (arrow). Lymphadenopathy was identified in the attached mesentery.
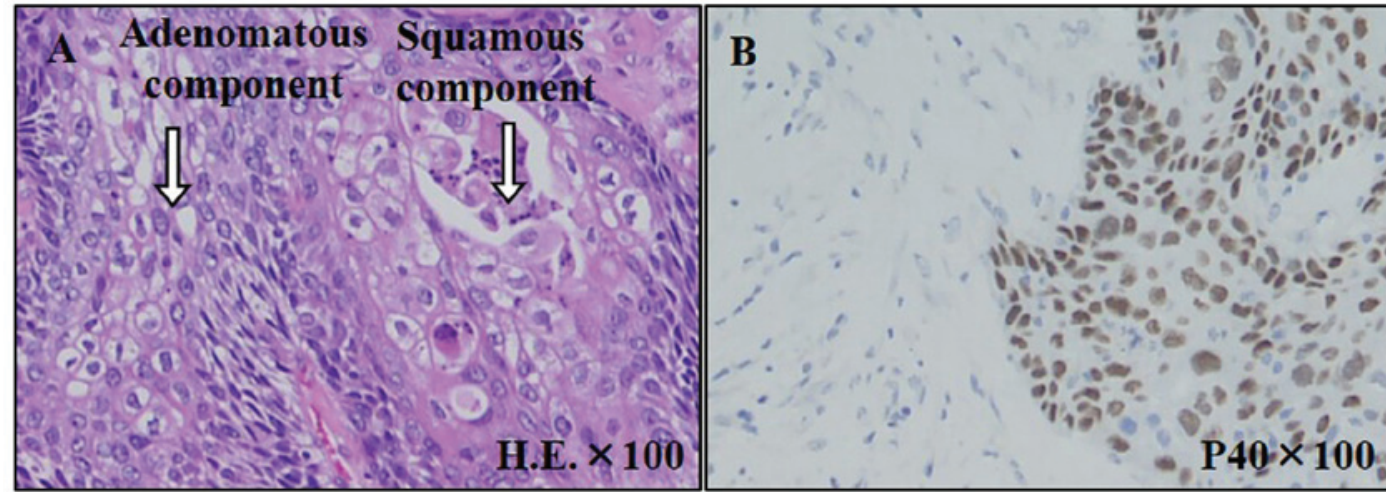

Figure 3. (A) Hematoxylin and eosin staining (H\&E; magnification, x100) showing the squamous and adenomatous component. (B) Immunohistochemical staining for P40 showing positivity of the squamous cell carcinomatous component (magnification, x100).

the lungs, pancreas, papilla of Vater, gallbladder, lung and breast (8-12). However, ASCC is a rare type of intestinal malignant tumor, with only 8 cases reported in the English literature to date. Due to its rarity, the clinicopathological characteristics and survival outcomes of intestinal ASCC have not been clearly determined. The previous reports are summarized in Table I (13-20). Almost all patients had abdominal pain as a chief complaint, and their median age was 76 years (range, 55-80 years). All patients presented with advanced-stage disease and underwent surgical procedures. Thus, the treatment for intestinal ASCC largely involve surgical intervention to remove intestinal obstructions. Of the 9 reported cases of small intestinal ASCC (including the present case), 4 were metastatic at the time of initial diagnosis. A total of 3 patients underwent adjuvant chemotherapy. Excluding patients who received chemotherapy, all patients succumbed to the disease within 1 year after undergoing surgery. There has been no evidence indicating which chemotherapy regimen is the best option. However, chemotherapy appears to be crucial for preventing recurrence when considering cases with poor prognosis. In the present case, the patient received XELOX and remains alive without recurrence 20 months after surgery. Due to the sparsity of reported cases of ASCC of the small intestine, a conclusion regarding its clinicopathological characteristics cannot yet be reached. ASCCs of the small intestine may exhibit aggressive biological behavior, similar to ASCCs in other organs, as compared to conventional adenocarcinoma $(21,22)$. In conclusion, ASCC arising from the small intestine is a rare entity. Therefore, accumulation of further evidence regarding its clinicopathological characteristics is crucial for establishing a standard therapy.

\section{Acknowledgements}

Not applicable.

\section{Funding}

No funding was received.

\section{Availability of data and materials}

All data generated in this case are included in this published article.

\section{Authors' contributions}

NF and KK wrote the initial draft of the manuscript with support from KD and KT. NF and YN performed the surgery. YH contributed to data collection and assisted in the preparation of the manuscript. All authors have read and approved the final version of the manuscript. 


\section{Ethics approval and consent to participate}

Not applicable.

\section{Patient consent for publication}

Written informed consent was obtained from the patient for publication of the case details and any accompanying images.

\section{Competing interests}

The authors declare that they have no competing interests to disclose.

\section{References}

1. Pan SY and Morrison H: Epidemiology of cancer of the small intestine. World J Gastroenterol Oncol 3: 33-42, 2011.

2. Bosman FT: International agency for research on C. World Health organization classification of tumors. International agency for research on cancer 4. Lyon: IARC Press, 2010. WHO classification of tumors of the digestive system.

3. Japanese gastric cancer association: Japanese gastric cancer treatment guidelines 2014 (ver. 4). Gastric Cancer 20: 1-19, 2017.

4. Watanabe T, Muro K, Ajioka Y, Hashiguchi Y, Ito Y, Saito Y, Hamaguchi $\mathrm{T}$, Ishida $\mathrm{H}$, Ishiguro $\mathrm{M}$, Ishihara $\mathrm{S}$, et al: Japanese society for cancer of the colon and rectum (JSCCR) guidelines 2016 for the treatment of colorectal cancer. Int J Clin Oncol 23 : 1-34, 2018.

5. Shimoji M, Nakajima T, Yamatani C, Yamamoto M, Saishou S, Isaka M, Maniwa T, Ode Y, Nakagawa K, Okumura T, et al: A clinicopathological and immunohistological re-evaluation of adenosquamous carcinoma of the lung. Pathol Int 61: 717-722, 2011.

6. Kardon DE, Thompson LD, Przygodzki RM and Heffess CS: Adenosquamous carcinoma of the pancreas: A clinicopathologic series of 25 cases. Mod Pathol 14: 443-451, 2001.

7. Yang SJ, Ooyang CH, Wang SY, Liu YY, Kuo IM, Liao CH and Wu TJ: Adenosquamous carcinoma of the ampulla of Vater-a rare disease at unusual location. World J Surg Oncol 11: 124, 2013.

8. He JJ, Ding KF, Zheng L, Xu JH, Li J, Wu YL, Sun LF, Zhou DE and Zheng S: Adenosquamous carcinoma of the uncinate process of the pancreas with synchronous gastrointestinal stromal tumor of the stomach: Case report and review of the literature. Oncol Lett 4: 1191-1194, 2012.
9. Ueno N, Sano T, Kanamaru T, Tanaka K, Nishihara T, Idei Y, Yamamoto M, Okuno T and Kawaguchi K: Adenosquamous cell carcinoma arising from the papilla major. Oncol Rep 9: 317-320, 2002.

10. Chen K, Xiong L, Yang Z, Huang S, Zeng R and Miao X: Prothymosin- $\alpha$ and parathymosin expression predicts poor prognosis in squamous and adenosquamous carcinomas of the gallbladder. Oncol Lett 15: 4485-4494, 2018

11. Du C, Li Z, Wang Z, Wang L and Tian YU: Stereotactic aspiration combined with gamma knife radiosurgery for the treatment of cystic brainstem metastasis originating from lung adenosquamous carcinoma: A case report. Oncol Lett 9: $1607-1613,2015$

12. Hashemi SM, Mahmoudi Shan S, Jahantigh M and Allahyari A: Atypical breast adenosquamous carcinoma following acute myeloid leukemia in a middle-aged woman: A case report. Mol Clin Oncol 6: 271-275, 2017.

13. Bjerregaard E: Adenoacanthoma of the small bowel: Report of a case. Acta Pathol Microbiol Scand 82: 113-115, 1974.

14. Griesser GH, Schumacher U, Elfeldt R and Horny HP: Adenosquamous carcinoma of the ileum: Report of a case and review of the literature. Virchows Arch A Pathol Anat Histopathol 406: 483-487, 1985.

15. Ng FC, Ang HK and Chng HC: Adenosquamous carcinoma of the ileum-a case report. Singapore Med J 34: 361-362, 1993.

16. Ngo N, Villamil C, Macauley W and Cole SR: Adenosquamous carcinoma of the small intestine. Report of a case and review of the literature. Arch Pathol Lab Med 123: 739-742, 1999.

17. Wada T, Mizuno K, Itoh K, Monoe T, Ando H, Kondo Y, Takada H, Ogawa K, Kanai M, Joh T and Itoh M: Adenosquamous carcinoma of the jejunum. J Gastroenterol 38: 786-790, 2003.

18. He YT, Wang XJ, Gong J, Chen N and Zhou Q: Primary adenosquamous carcinoma of the jejunum. Pathol Int 55: 590-595, 2005.

19. TakayoshiK, Ariyama H, Tamura S, Yoda S, Arita T, Yamaguchi T, Ozono K, Yamamoto $\mathrm{H}$, Inadomi $\mathrm{K}$, Kumagai $\mathrm{H}$, et al: Intraluminal superior vena cava metastasis from adenosquamous carcinoma of the duodenum: A case report. Oncol Lett 11: 605-609, 2016

20. Daga G and Kerkar P: Adenosquamous carcinoma of the duodenum: A rare entity. Indian J Surg Oncol 7: 470-474, 2016.

21. Komatsu H, Egawa S, Motoi F, Morikawa T, Sakata N, Naitoh T, Katayose Y, Ishida K and Unno M: Clinicopathological features and surgical outcomes of adenosquamous carcinoma of the pancreas: A retrospective analysis of patients with resectable stage tumors. Surg Today 45: 297-304, 2015.

22. Samuel S, MukherjeeS, Ammannagari N,Pokuri VK,KuvshinoffB, Groman A, LeVea CM and Iyer R: Clinicopathological characteristics and outcomes of rare histologic subtypes of gallbladder cancer over two decades: A population-based study. PLoS One 13: e0198809, 2018. 